\title{
P45＼cjkstart積層アルミハニカムサンドイッチパネルの圧縮特性に関する研究
}

\author{
$\bigcirc$ 佐藤岳大（武蔵工大院），正 大塚年久（武蔵工大） \\ 正 田村 宏（武蔵工大），正 小林志好（武蔵工大）

\section{Study on Compressive Property of Laminated Aluminum Honeycomb Core Sandwich Panel} \\ Takehiro SATOH, Toshihisa OHTUKA, \\ Hiroshi TAMURA and Yukiyoshi KOBAYASHI \\ Musashi Institute of Technology, 1-28-1, Tamazutumi, Setagaya-ku, Tokyo, 158-8557, Japan
}

\section{1. 緒 言}

ハニカムサンドイッチパネル（以下，パネルと称 する）は，コア材の座屈による安定から効率的なエネ ルギ吸収性を有する．その特性は，パネルを構成する コア材や表面板の配置の仕方などにより変化する. 現 在, 緩重材等に単層パネルが使用されているが，より 高強度, 高エネルキ吸収性を必要とする場合, 積層パ ネルによる代用が考えられる.このとき, 圧縮荷重下 でのパネルの変形挙動が, 自身の強度やエネルギ吸収 性に影響を及ぼす、本研究は，特に異なるセル壁厚さ のコアを積層させたパネルの座屈特性に注目し, 積層 パネルの静的全面圧縮試験を行った. 得られた結果よ り, 圧縮座屈強度と圧縮変形時のコアの座屈による工 ネルギ吸収性について考察した. また，単層パネルと の比較を行い, 積層パネルの優位性について検討した.

\section{2. 試験方法}

21 試酫片 試験片は, 表面板, コア材とも A1100 を用いた. 表面板の厚さは $03 \mathrm{~mm}$ ，コアのセルサイズ は 8.7mm とし, シングルウォール部のセル壁厚さ $\mathrm{t}$ は, $0.04 \mathrm{~mm}, 0.05 \mathrm{~mm}, 0.08 \mathrm{~mm}$ の 3 種類とした. 表面板と コアの接着戍には、ニューポート社製 NB-102 を用い た.

試験片の形状は，コアを2 層積層したものとし， その上下面とコア間に，アルミ板をそれぞれ接着した. 以下，上に接着したアルミ板を上板，コア間に挟んだ アルミ板を中板と称する. 試験片の外形寸法は長さ

Table 1 Thickness of cell wall.

\begin{tabular}{c|c|c}
\hline \hline Specimen & Upper layer $[\mathrm{mm}]$ & Lower layer $[\mathrm{mm}]$ \\
\hline $\mathrm{A}(\mathrm{t} 45)$ & 0.04 & 0.05 \\
\hline $\mathrm{B}(\mathrm{t} 54)$ & 0.05 & 0.04 \\
\hline $\mathrm{C}(\mathrm{t} 58)$ & 0.05 & 0.08 \\
\hline $\mathrm{D}(\mathrm{t} 85)$ & 0.08 & 0.05 \\
\hline $\mathrm{E}(\mathrm{t} 4)$ & 0.04 & - \\
\hline $\mathrm{F}(\mathrm{t})$ & 0.05 & - \\
\hline $\mathrm{G}(\mathrm{t})$ & 0.08 & - \\
\hline
\end{tabular}

$50 \mathrm{~mm}$ ，幅 $50 \mathrm{~mm}$ とし，コア高さは上下コアとも $10 \mathrm{~mm}$

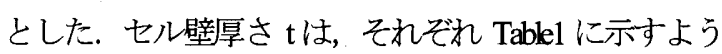
に決定した. 比較材としての単層パネル $\mathrm{E} \sim \mathrm{G}$ のコア 高さは，それぞれ 10mmとした。

2.2 試験方法 全面圧縮試験は, 板厚方向に変位 速度 $1 \mathrm{~mm}$ min で行った. また, 試験中のパネルの座屈 特性を調へるために, 上板, 中板の板厚方向の変位を それぞれクリップゲージにて測定した。

\section{3. 試験結果およひ考察}

3.1 荷重 - 変位線図 試験の結果から, セル壁厚 さ $\mathrm{t}$ 異なる試験片は, $\mathrm{t}$ 薄いコアが上下の位置に関 わらず先に座屈し，そのコアがほぼ潰れきった後にも う一方のコアが座屈することが観察された. 以下, 座 屈した順番を考慮し，先に座屈したものを 1stコア， 後から座屈したものを 2 d コアと称する.

Fig1に，結果の一例として試験片 B の荷重 - 変位

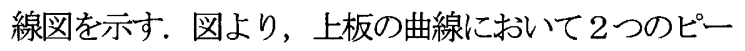
クをとり，それらの直前には線形領域があることがわ かった. 以下，それらのピーク值を 1 次ピーク值 $\mathrm{P} 1$, 2 次ピーク值 $\mathrm{P} 2$ と称する. なお, 他試験片について も P1，P2の出現に関しては同傾向の曲線を描いた.

Fig2 に; 試験片 B の 1st，2nd コアの荷重 - 座屈量線 図を示寸，図より，P1，P2 以降に1st，2ndコアがそれ ぞれ降伏座屈していた．2つのピーク後の荷重上昇は， コアが緻密化に至ったため起こった。

以上の結果を踏まえると, 積層パネルの変形挙動 は2つのコアそれぞれに分けて考察することができる. よって，以下に積層パネルのそれぞれのコアの特性と， 同じセル壁厚さの単層パネルの特性を比較する.

32 ピーク值に及ぼすコアの影缼 Fig3に全試験片 の $\mathrm{P} 1 ， \mathrm{P} 2$ を示す. まず, P1について積層パネルと単 層パネルの值を比較する. 試験片 A，B の P1 は訪験

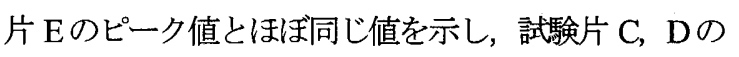
P1 は試験片 F のピーク值よりやや大きな值を示した. これより，P1 の值は座屈するコアの強度に基本的に 


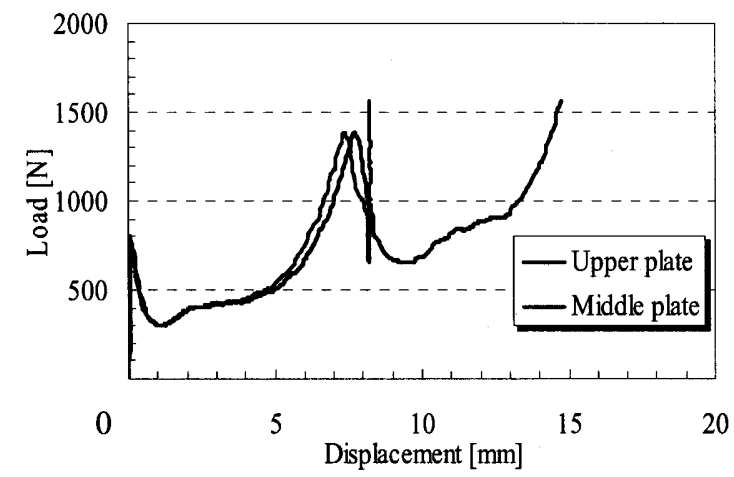

Fig1 Load-displacement curves (Specimen B).

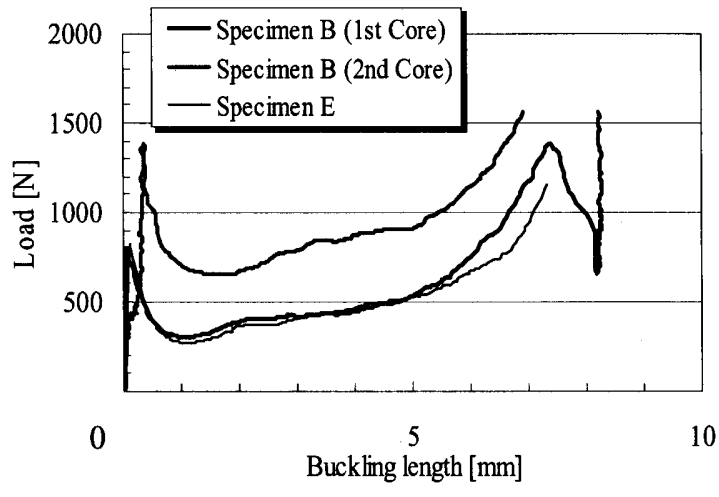

Fig.2 Load-buckling curves (Specimen B,E).

依存すると考えられる.

次に，P2について積層パネルと単層パネルの值を 比較する. 試験片 A，B とほぼ同じ值を示し, 試験片 C, D の P2 は試験片 G のピーク值よりやや小さな值を示した. これより，P2 の值は P1 の值と同様に座屈するコアの強度に基本的 に依存すると考えられる.

\section{3 コアの座届に関する吸収エネルギパネルは，} コアの座屈による優れたエネルギ吸収性が期待できる。 そこで以下に，エネルギ特性について考察する. コア の座屈量に着目し，パネル全体がコアの緻密化へ至る までに受けた荷重と座屈量の積分量を，コアの座屈に 関する吸収エネルギ（以下，座屈エネルギ W と称す る），荷重と各コアの座屈量の積分量を，各コアの座 屈エネルギ（以下，1st コアの座屈エネルギを W1, 2nd コアの座屈エネルギを W2 と称する）として求め, 考察する，なお，W=W1+W2である．Fig4 に，全試験 片のWおよびW1，W2を示す.

まず，W2 について積層パネルと単層パネルの值を 比較する，試験片 $\mathrm{A} ， \mathrm{~B}$ の W2 と試験片 $\mathrm{F}$ の W，試験 片 C，Dの W2 と試験片 $\mathrm{G}$ の W を比較すると，いず れもほぼ等しい值を示した. 積層パネルの 2nd コアと 単層パネルの変形挙動がほぼ同じだったため, W の

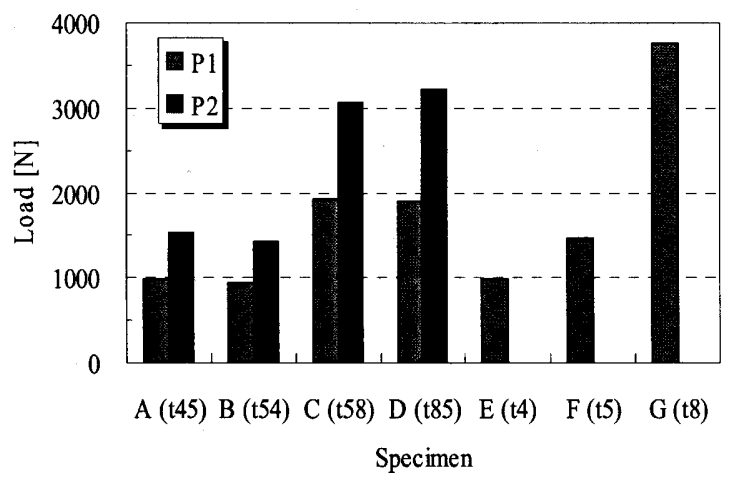

Fig.3 Load values of first and second peaks.

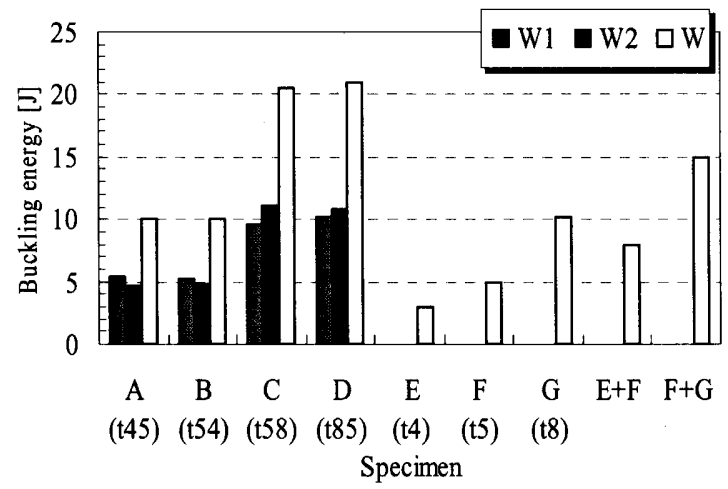

Fig.4 Buckling energy.

値はほぼ等しくなった。

次に, W1 について積層パネルと単層パネルの值を 比較する．試験片 $\mathrm{A} ， \mathrm{~B}$ の $\mathrm{W} 1$ と試験片 $\mathrm{E}$ の W, 試験 片 C，Dの W1 と試験片 $\mathrm{F}$ の W 比較すると，いずれ も積層パネルのW1が Wより大きな值を示した．Fig2 に，試験片 Eの荷重 - 座屈量線図を加えて示し，試験 片 Bの 1stコアの曲線と試験片 $\mathrm{E}$ の曲線を比較する.

図より, 積層パネルの 1st コアは, 単層状態より大き な荷重が負荷され，緻密化に至るまでの座屈量も増え たことがわかる. 積層パネルに負荷された 2 次ピーク に至る荷重が，座屈を効率的に促進させたため，エネ ルギ吸収量が増えたと考えられる。

$\mathrm{W}$ について, 積層パネルの $\mathrm{W}$ と単層パネルの $\mathrm{W}$ を合わせた值を比較する．上記した考察より，W1> $\mathrm{W}$ (単層パネル) であるので，いずれも積層パネルの $\mathrm{W}$ が単層パネルを合わせたよりも大きい，これより， エネルギ吸収の点て積層パネルが有効であると言える.

\section{4. 結 言}

積層パネルの全面圧縮試験を行った結果, 積層パ ネルの変形はそれぞれの層の変形に分けて考えること ができることがわかった．単層パネルの特性と比較す ると, 圧縮座屈強度はあまり変わらないが，コアの座 屈によるエネルギ吸収性は向上することがわかった. 